\title{
Global Production Network: Participation and Structural Break
}

\author{
Agus Miftahul Ilmi \\ Graduate Program in Economics Science, \\ Faculty of Economics and Business, University of Indonesia \\ Depok, Indonesia \\ agus.ilmi@gmail.com
}

\author{
Fithra Faisal Hastiadi \\ Department of Economics, \\ Faculty of Economics and Business, University of Indonesia \\ Depok, Indonesia \\ fithra_faisal@yahoo.com
}

\begin{abstract}
International trade for intermediate goods has increased along with the development of the Global Production Network. Contemporary debates are on opportunity to benefit from economic globalization by linking production into global production network. Recent specific studies identify the determinants of participation involved using various methodologies, but are less detailed on discussing some economic shocks embodied within. Although in its development, the global production network was affected by the economic crisis in Asia in 1997/1998 and the 2008/2009 economic shock which caused trade contraction. By using fixed effect regression with LSDV in model, this study aims to answer the question whether by considering the trade contraction as a structural break in the study will portrait the close relationship between trade contraction with participation of global production network. The results show that the economic crisis of $1997 / 1998$ and the economic shock of 2008/2009 have a causal relation to the participation of the global production network.
\end{abstract}

Keywords-Economic Crisis; Economic Shock; Fragmentation Theory; Global Production Network; Structural Break; Trade Contraction

\section{INTRODUCTION}

International trade for semi-finished goods has increased along with the development of the Global Production Network (GPN) and the spread of distribution among countries. The phenomenon shows that the division of global production forms a new economic pattern and occurs almost all over the world. Meanwhile, countries in East Asia which are the pioneers in the development of this economic pattern, have been running for 3 decades. Developed and developing countries jointly interconnect production and distribution facilities for shared economic benefits.

The debates are on the opportunity to reap gain from globalization of economic by participating in global production networks. The level of participation has been measured by several studies with various methodologies. Recent studies have shown empirical data and evidence of linkages or participation in GPN. An example is the Ando and Kimura (2005) research that identified the international production/distribution network at the company level in the machinery industry (General, Electrical, transport equipment, and precision machinery).

Researches specifically identifying the determinants of participation in GPN evolved by using various

The author is grateful to Mrs. Arie Damayanti and Mr. Vid Adrison on behalf of Graduate Program of Economics Science, Univesity of Indonsia. methodologies. The research of Kimura et al. (2007) and Athukorala (2011) formulated the determinants of participation in global production network by applying gravity method. Meanwhile Kowalski et al. (2015) measured the participation of developing countries in GVC using regression based on Domestic Value Added. Banga (2014) studied how to measure a country's participation in the Global Value Chain (GVC) through the forward linkage ratio of backward linkage, in which GVC is a value added term of a global production network based on a concept developed by Koopman et al. (2011). Meanwhile, the determinants of global production network participation formulated by Soejachmoen (2014) are specifically on the automotive industry of 98 developed and developing countries based on the theory of production fragmentation initiated by Jones dan Kierkowski (1990).

In its development, the global production network was also affected by the economic crisis in Asia in 1997/1998 and the economic shock in 2008/2009 which caused contractions in both periods. The WTO report $^{1}$ stated that the 1997/1998 Asian economic crisis caused the world trade to weaken due to the declining demands from Asian countries in terms of petroleum, capital goods and industrial commodities. In the period of 1997/1998 , export performance from Asian countries significantly declined accompanied by falling real currency values and rising unemployment. The economic globalization (integrations of production and inter-state finance) in Asia since the 1980s has been linked to the rapid escalation of economic shock. Indonesia was facing the worst economic crisis where the GDP fell to $23 \%$ in the period of 1996-1998; the same thing faced by South Korea, Japan, and followed by other Asian countries.

In various studies, the economic shock in 2008/2009 was also allegedly linked to the development of the global production network. Krugman in [14] stated that the vertical integration of global production was more likely caused by the great contraction of trade in the 2008/2009 crisis compared to the Great Depression in 1928. Athukorala in [4] also explained that in 2008 the trade contraction by East Asian countries felt greater than the contraction of world trade. Among East Asia countries, Japan was most affected by the crisis in 2008 due to reduced demand for final goods exports to China [7], as well

${ }^{1}$ WTO Annual Report 1998, The Asian financial crisis and the multilateral trading system, Chapter 3 page 25-28. 
as reduced demand for capital goods and high end consumer durables goods to America and Europe [4].

The academic debates are on the opportunity to benefit from globalization of economic through participation in GPN. Given the condition of economic shock occurring, then it is necessary to do further research. It is important to consider the trade contractions occurring in both the 1997/1998 economic crisis and the 2008/2009 economic shock at deeper levels of research analysis; thus, a better understanding on the relationships between variables will be achieved. In the existing researches, the participation of global production network has not considered the condition of trade contraction, whereas it is allegedly very influential on the research results. This study aims to answer the question whether by considering the contraction of trade, as a structural break in the study, will show the causality relationship between trade contractions and the participation of global production network. Applying structural break as a technique in analyzing the research is expected to result a clearer picture on the causal relationship between trade contraction and the participation of global production network; so that the economic phenomena become consideration in future studies.

\section{CONCEPTUAL FRAMEWORK}

\section{A. Fragmentation Theory}

Fragmentation theory was developed by Jones \& Kierkowski (1990), where an integrated production process is broken down into separate stages (production block) in order to optimize profits with specialization of production as shown in Fig. 2. A multinational company will conduct a global production network pattern if the total cost efficiency can be obtained, by fragmentation of production into a smaller segment of production at a particular location, by considering the comparative advantages (difference of factor endowment) and economic scale \& economic scope [6].

The rapidly growing international production and distribution formation in East Asia are important and well known phenomena of the past two decades. The global economic trends can be well explained by the theory of fragmentation [10]. This is because the Fragmentation theory has contributed factors:

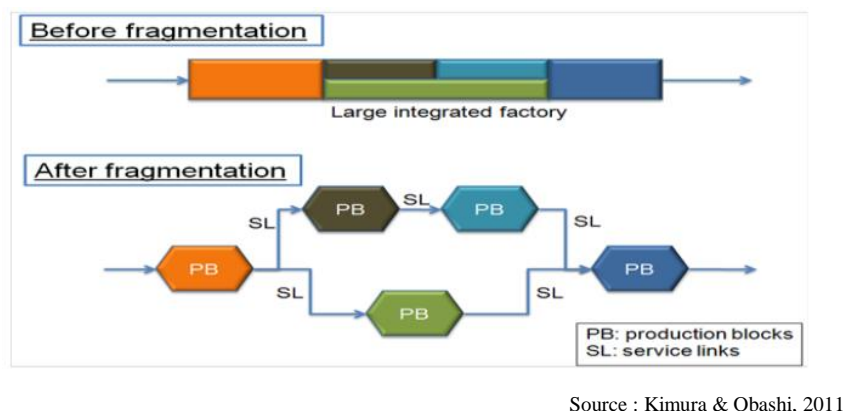

Fig. 1. Production Network

first, developments in production technologies that enable cutting up the production process into several blocks of different production process; second, Trade Liberalization and third, progress in terms of communication and transportation (services link).

Traditional trading theories such as Ricardian's productivity factor and Heckscher-Ohlin's price and intensity factor are still relevant to the fragmentation theory because the decision of the production block's specialization location depends on the comparative advantage. The fragmentation theory involves more than 2 types of goods (unfinished goods / parts and components); it is influenced by the relative cost and the service link efficiency between related countries. Thus, makes it more complex than the other theory. [3]. The service links in international trade according to Kimura \& Takahashi (2004) are trade cost, investment, communication cost and coordination cost.

Based on production technology aspect, Lall, Albaladejo, \& Zhang (2004) explained that fragmentation depends on 4 factors, that is technical divisibility, the intensity factor of the process, technological complexity of every production process, and value-to weight ratio.

\section{B. Fragmentation in Economic Shock's}

The trade contraction that occurred during the recession and economic crisis caused the instability of exchange rate, the decrease of demand for goods and excess supply of goods, so that producer countries tend to adjust production [4] [7]. Under such circumstances, a multinational corporation having a fragmentation pattern of production in the host country will consider to relocate one or more of their production blocks for adjustment, or even decide to stop production. This will affect the level of host country participation in the global production network; so that the country will tend to undertake various leeway policies in the framework of investment and distribution of their products to maintain the economic and trade stability.

\section{DATA AND EMPIRICAL MODEL}

Step-1:

A comparative perspective of the host country was used as a model basis with relative production factors and service link factors as the main components according to the fragmentation theory of Jones and Kierzkowski (1990). The empirical model to identify the determinants of participation made by Soejachmoen (2014) is still relevant in this study; so that it was used as a key reference. Some control variables reflecting the characteristics of the industrial sector was added and more precise data sources was used.

In principle based on Lall et al. (2004), fragmentation can be realized if the cost saving of multinational companies has considered 4 factors of production technology; those are technical divisibility in production process, intensity factor of process, technological complexity of each production process and trade value to weight ratio. Each industry has different weighting scores to describe the characteristics. Of the four factors of proximity, trade value to weight ratios data could be obtained and was used in this study as proximity for the characteristics of the industrial sector. As Kimura's research, 
TABLE I. INDUSTRIAL PRODUCT CLASSIFICATION

\begin{tabular}{|c|c|}
\hline Classification & Industrial Included \\
\hline Machinery & $\begin{array}{l}\text { - Power generating machines (SITC 71) } \\
\text { - Specialized industrial machine (SITC 72) } \\
\text { - Metal working machine (SITC 73) } \\
\text { - General industrial machinery (SITC 74) }\end{array}$ \\
\hline ICT products & $\begin{array}{l}\text { - Office machines and automatic data processing } \\
\text { machines (SITC 75) } \\
\text { - Telecommunication and sound recording equipment } \\
\text { (SITC 76) } \\
\text { - Semiconductors and semiconductor devices (SITC } \\
\text { 772 + SITC 776) } \\
\text { - Electrical goods (SITC } 77 \text { - SITC } 772 \text { - SITC 776) }\end{array}$ \\
\hline $\begin{array}{l}\text { Transport } \\
\text { Equipment }\end{array}$ & $\begin{array}{l}\text { - Road vehicles (SITC 78) } \\
\text { - Other transport equipment (SITC 79) }\end{array}$ \\
\hline $\begin{array}{l}\text { Resourced } \\
\text { Based Product }\end{array}$ & $\begin{array}{l}\text { - Leather (SITC 61) } \\
\text { - Rubber (SITC 62) } \\
\text { - Textile yarn and fabrics (SITC 65) } \\
\text { - Non-metallic mineral (SITC 66) } \\
\text { - Metals (SITC 69) }\end{array}$ \\
\hline $\begin{array}{l}\text { Other } \\
\text { Manufacturing }\end{array}$ & $\begin{array}{l}\text { - Chemicals (SITC 5) } \\
\text { - Miscellaneous manufacturing (SITC 8) } \\
\text { - Professional and scientific equipment (SITC 87) } \\
\text { - Photographic apparatus (SITC 88) }\end{array}$ \\
\hline
\end{tabular}

this model would accommodate GDP percapita variable to capture the impacts of the economic advancement level on export performance.

This study used trade data of intermediate goods (SITC Rev. 3) from 40 countries in Asia, Europe, America and Africa which were considered to represent global production and distribution patterns according to the research scope of Athukorala [3]. The dependent variable is the real export value of intermediate goods (including parts and components). The estimation used fixed effect regression with Least Square Dummy Variable (LSDV) to see the portrait of each country from 1988 to 2015 by regressing all industrial sectors. The industrial product classification is shown in Table I.

\section{Step-2:}

Using the model specification in step I, the regression was done by structural break considering the condition of economic crisis in 1997/1998 and the economic shock in 2008/2009. Structural break was divided into three periods, first is in the period of 1988 to1997, second is in 1999 to 2007 and third is during period of 2009 to 2015.

\section{EMPIRICAL RESULT}

\section{A. Participation of Global Production Network}

An estimation according to the methodology in step 1 was obtained from the fixed effect regression resulting items as shown in Table III. The discussion begins by looking at test results for all scopes of the industrial sectors during the period of 1988-2015. It shows that almost all independent variables have positive and significant relations to real export variables including Labor Cost and Real Exchange Rate (RER). This is in accordance with the results of the Soejachmoen (2014) which became the model reference on the determinants of global production network participation.
TABLE II. VARIABLES AND OPERATIONAL DEFINITIONS

\begin{tabular}{|c|c|}
\hline Variables & Operational Definitions \\
\hline $\operatorname{Frag}_{i, t}$ & $\begin{array}{l}\text { Fragmentation trade, real value of export of parts and } \\
\text { components of country } \mathrm{i} \text { in year } \mathrm{t} \text {. }\end{array}$ \\
\hline LabCost $_{\mathrm{i}, \mathrm{t}}$ & $\begin{array}{l}\text { Cost of labor, is the real labor wage for country } i \text { in } \\
\text { year t. }\end{array}$ \\
\hline $\mathbf{R E R}_{\mathrm{i}, \mathrm{t}}$ & $\begin{array}{l}\text { Real Exchange Rate, shows the competitiveness of } \\
\text { country } i \text { in year t. }\end{array}$ \\
\hline TradeCost $_{\mathrm{i}, \mathrm{t}}$ & $\begin{array}{l}\text { Trade Cost, is the export cost of product from country } \mathrm{i} \\
\text { in year } t\end{array}$ \\
\hline TradeOpen $_{\mathrm{i}, \mathrm{t}}$ & $\begin{array}{l}\text { Trade openness in the year } t \text {, ratio of total export and } \\
\text { import to GDP from country } i \text { in year } t\end{array}$ \\
\hline Infrastructure & $\begin{array}{l}\text { Logistic Performance Index, in country } \mathrm{i} \text { and period } \mathrm{t} \\
\text { year }\end{array}$ \\
\hline FDIOpen $_{\mathrm{i}, \mathrm{t}}$ & $\begin{array}{l}\text { FDI Openness, the ratio of FDI stock to GDP from } \\
\text { sector } \mathrm{i} \text { in year } \mathrm{t}\end{array}$ \\
\hline VTWR $_{i, t}$ & $\begin{array}{l}\text { Trade Value to Weight Ratio, shows the characteristics } \\
\text { of the industrial sector, is the ratio of Export value to } \\
\text { total weight of commodity sector in year t }\end{array}$ \\
\hline $\begin{array}{l}\text { Dummy } D \\
\text { and } T\end{array}$ & $\begin{array}{l}\text { Dummy of certain country character and Dummy time } \\
\text { (Time varying) to consider certain conditions at certain } \\
\text { period. }\end{array}$ \\
\hline $\mathbf{a}_{\mathbf{i}}$ & $\begin{array}{l}\text { Intercept for country } i \text {, is an indicator of the } \\
\text { characteristics of participation of each country. }\end{array}$ \\
\hline
\end{tabular}

Source : Soejachmoen (2014) with adjustment

Economic advancement of a country to improve export performance, proxied by GDP percapita shows significant estimation results (error rate less than 1\%) in all estimation groups. The export performance includes export parts and components that reflects the participation of GPN. It supports the opinions of Athukorala (2011) and Kimura et al. (2007) which preferred to use the theory of gravity in their studies.

The industry characteristics reflected from the variable value to weight ratio (vtwr) empirically show significant differences in inter-industry constant values. The industrial sector of ICT (coeff. 0.230), has the greatest influence on the participation rate of global production network, followed by the transport equipment industry (coeff. 0.145), resourced based industry (coeff. 0.121) and machinery industry (coeff. 0.082), while the rest industries are shown in other manufacturing groups. So it can be concluded that industry characteristics greatly affect the level of participation in GPN. This further reinforces the opinions of the Lall et al. (2004) and Sturgeon (2010).

The intercept of estimation shows a picture of the country participation level in the global production network. In general, among 5 ASEAN countries the highest participation level is Malaysia followed by the Philippines, Singapore, Thailand and Indonesia. Malaysia has a higher level of participation in almost all industries, except the transport equipment industry which is lagged behind Thailand and Philippines. These results support the results of Soejachmoen (2014) stating that the Indonesian automotive industry is left behind Thailand in the participation of GPN. 
TABLE III. ESTIMATION RESULT

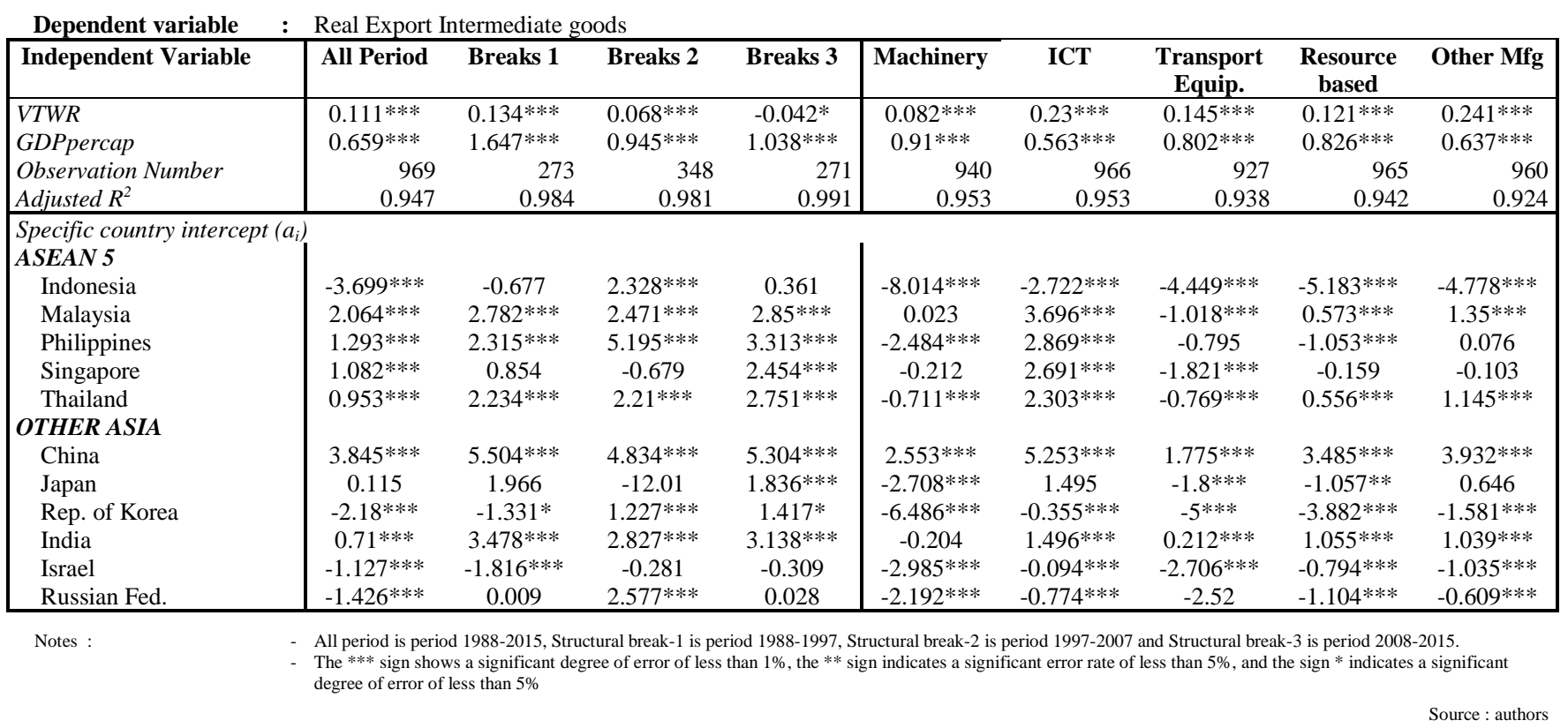

Countries in other Asian regions, China and India are at the highest level of participation in all industries. The strength of the Chinese economy is undoubtedly where the rapid development of industrial and logistics infrastructure are supported by labor skills with competitive wages in all industrial sectors. Meanwhile, India is a developing country with high GDP growth ${ }^{2}$ that supports the linkages in the global production networks. Japan has spread their economy into many developed and developing countries. Domestic development is more on high-tech industries; observing the whole wide scope of the production networks is necessary to analyze.. Korea is experiencing rapid growth in the ICT industry and began to build their production networks in various countries; though sectorial competition with other countries still requires maximum effort, including with Israel and Russia.

TABLE IV. THE ORDER OF PARTICIPATION LEVEL OF GLOBAL PRODUCTION NETWORK OF EACH INDUSTRIAL GROUPS

\begin{tabular}{|c|c|c|c|c|c|c|c|}
\hline Region & Ord. & All & Mach. & ICT & $\begin{array}{l}\text { Transp. } \\
\text { Equip. }\end{array}$ & $\begin{array}{c}\text { Res. } \\
\text { based }\end{array}$ & $\begin{array}{l}\text { Other } \\
\text { Mfg. }\end{array}$ \\
\hline $\begin{array}{c}\text { ASEAN } \\
5\end{array}$ & $\begin{array}{l}1 \\
2 \\
3 \\
4 \\
5\end{array}$ & $\begin{array}{l}\text { Malay. } \\
\text { Philipp. } \\
\text { Sing. } \\
\text { Thailand } \\
\text { Indonesia }\end{array}$ & $\begin{array}{l}\text { Malay. } \\
\text { Sing. } \\
\text { Thailand } \\
\text { Philip. } \\
\text { Indonesia }\end{array}$ & \begin{tabular}{|c|} 
Malay. \\
Philipp. \\
Sing. \\
Thailand \\
Indonesia
\end{tabular} & $\begin{array}{l}\text { Thailand } \\
\text { Philipp. } \\
\text { Malay. } \\
\text { Sing. } \\
\text { Indonesia }\end{array}$ & \begin{tabular}{|c|} 
Malay. \\
Thailand \\
Singapore \\
Philipp. \\
Indonesia
\end{tabular} & $\begin{array}{l}\text { Malay. } \\
\text { Thailand } \\
\text { Philip. } \\
\text { Sing. } \\
\text { Indonesia }\end{array}$ \\
\hline $\begin{array}{c}\text { OTHER } \\
\text { ASIA }\end{array}$ & $\begin{array}{l}1 \\
2 \\
3 \\
4 \\
5 \\
6\end{array}$ & $\begin{array}{c}\text { China } \\
\text { India } \\
\text { Japan } \\
\text { Israel } \\
\text { Russian } \\
\text { Korea }\end{array}$ & $\begin{array}{c}\text { China } \\
\text { India } \\
\text { Russian. } \\
\text { Japan } \\
\text { Israel } \\
\text { Korea }\end{array}$ & $\begin{array}{c}\text { China } \\
\text { India } \\
\text { Japan } \\
\text { Israel } \\
\text { Korea } \\
\text { Russian }\end{array}$ & $\begin{array}{c}\text { China } \\
\text { India } \\
\text { Japan } \\
\text { Russian } \\
\text { Israel } \\
\text { Korea }\end{array}$ & $\begin{array}{c}\text { China } \\
\text { India } \\
\text { Israel } \\
\text { Japan } \\
\text { Russian } \\
\text { Korea }\end{array}$ & $\begin{array}{c}\text { China } \\
\text { India } \\
\text { Japan } \\
\text { Russian } \\
\text { Israel } \\
\text { Korea }\end{array}$ \\
\hline
\end{tabular}

${ }^{2}$ GDP Growth in average from 2000-2016 is 7,03\% for India, $8.9 \%$ for China, $5.5 \%$ for Indonesia,

$5.15 \%$ for Malaysia and $3.3 \%$ for Thailand, source from WDI-World bank database.

\section{B. Effect of Structural Break in the Model}

Intercept estimation results (with breaks) of each country which represent the country participation level in the global production network has been processed and resulted an order of participation as shown in Table V. In the 1 st break period the order of participation rates from the highest is Malaysia, Philippines, Thailand, Singapore and Indonesia. In the second break period the order of participation rates from the highest is the Philippines, Malaysia, Indonesia, Thailand and Singapore. In the 3rd break period the order of participation level from the highest is the Philippines, Malaysia, Thailand, Singapore and Indonesia. In the table, the question arises whether the long-term participation rate of the Philippines is higher than Indonesia.

Based on the ratio of part and component exports to imports in Fig.2, the import value of Indonesia in the 1st break period was greater than the exports value; yet the export rate was increased to slowly reduce the value of negative ratios.

TABLE V. ORDER OF PARTICIPATION LEVEL OF GLOBAL PRODUCTION NETWORK IN THE PRESENCE OF STRUCTURAL BREAK

\begin{tabular}{|c|c|c|c|c|l|}
\hline Regional & Order & $\begin{array}{c}\text { All Period } \\
\mathbf{( 1 9 8 8 -} \\
\mathbf{2 0 1 5}\end{array}$ & $\begin{array}{c}\text { Breaks 1 } \\
\mathbf{( 1 9 8 8 - 1 9 9 7 )}\end{array}$ & $\begin{array}{c}\text { Breaks 2 } \\
(\mathbf{1 9 9 7 - 2 0 0 7})\end{array}$ & $\begin{array}{c}\text { Breaks 3 } \\
\mathbf{( 2 0 0 9 -} \\
\mathbf{2 0 1 5})\end{array}$ \\
\hline ASEAN5 & 1 & Malaysia & Malaysia & Philippines \\
& 2 & Philippines & Philippines \\
& 3 & Singapore & Thailand & Malaysia \\
Indonesia & Malaysia \\
& 4 & Thailand & Singapore & Thailand & Singapore \\
& 5 & Indonesia & Indonesia & Singapore & Indonesia \\
\hline OTHER & 1 & China & China & China & China \\
ASIA & 2 & India & India & India & India \\
& 3 & Japan & Japan & Russian & Japan \\
& 4 & Israel & Russian & Korea & Korea \\
& 5 & Russian & Korea & Israel & Russian \\
& 6 & Korea & Israel & Japan & Israel \\
\hline
\end{tabular}

Source: authors 


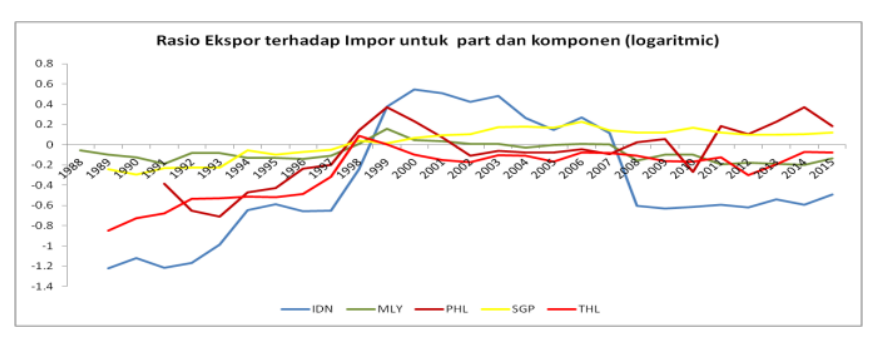

Source: authors, from UNCOMTRADE

Fig. 2. Ratio of export to Import for Parts and components 5 ASEAN countries (logaritmic)

In the second break period the ratio jumped positively due to significantly reduced imports of parts and components after the 1997/1998 economic crisis. It can be explained that Indonesia had been de-industrialized since 2001 which indicated that Indonesia's manufacturing export value relative to GDP tended to decrease over time. In addition, the postcrisis capital of 1997/1998 affected the economic condition of Indonesia. (Nurunnisa \& Hastiadi, 2017). At the 3rd break imported parts and components returned higher than their exports. It is suspected that the imported parts and components were mostly assembled and marketed domestically.

\section{CONCLUSION AND RECOMMENDATION}

From this study, it can be concluded that:

1. Industrial characteristics still greatly affect the participation rate of global production network with ICT industry (electronics and telecommunication) having the highest participation level, followed by transportation industry, resource based industries (rubber, metal, cotton and yarn, minerals) and machinery (Industrial machinery and generators).

2. Trade contractions that occurred in the economic crisis of $1997 / 1998$ and the economic shock of 2008/2009 affect the participation level in global production network in certain period, especially in Asia..

3. The use of structural break in this research is very important to see the changes of participation rate in short term, and picture specific economic condition of a country in a certain period.

This research still has some shortcomings such as:

1. Export data used in this study are export reports from home countries. There is a possibility of bias in certain countries that export through 3rd party, for example Indonesia that often exports through Singapore. The use of export data sourced from import reports from destination countries may be applied in future research to avoid such bias.

2. This study has limitations to prove empirically the relationships of economic volatility conditions that affect the participation level of global production network. Showing the reverse direction where the participation rate of global production network affects the acceleration of the propagation of economic shock may be considered in further research.

\section{REFERENCES}

[1] Ando, M., and Kimura, F., "The Formation of International Production and Distribution Networks in East Asia. International Trade in East Asia," NBER-East Asia Seminar on Economics (Vol. 14), 2005.

[2] Arndt, Sven W. And Kierzkowski, Hendryk "Fragmentation: New Production pattern in the World Economy", Oxford University Press, 2003.

[3] Athukorala, P., "Production Networks and Trade Patterns in East Asia: Regionalization or Globalization? ".ADB Working Paper Series on Regional Economic Integration, (56), 2010.

[4] Athukorala, P. ," Production Networks and Trade Patterns in East Asia: Regionalization or Globalization?,' Asian Economic Papers, 10(1), 6595, 2011.

[5] Banga, R.," Linking into Global Value Chains Is Not Sufficient: Do You Export Domestic Value AddedContents?," Journal of Economic Integration, 29(2), 267-297, 2014.

[6] Dunning, J. H., \& Lundan, S. M., "Multinational Enterprises and the Global Economy", Second Edition, Cheltenham: Edward Elgar Publishing Limited, 2008.

[7] Fukao, K. and Yuan, T., "Why Is Japan So Heavily Affected by the Global Economic Crisis? An analysis based on the Asian international input-output table", www.voxeu.org, 2009.

[8] Jones, R. W., and Kierkowski, H., "The role of services in production and international trade: a theoretical framework," In The Political Economy of International Trade: Essays in Honor of Robert E. Baldwin, Ed. RW Jones, A Krueger, 17-34, 1990.

[9] Kimura, F., and Obashi, A., "Production Networks in East Asia: What We Know So Far," 2011.

[10] Kimura, F., and Takahashi, Y.,'International Trade and FDI with Fragmentation: the Gravity Model Approach, " Unpublished Working Paper, (September), 1-43, 2004.

[11] Kimura, F., Takahashi, Y., and Hayakawa, K.," Fragmentation and parts and components trade: Comparison between East Asia and Europe," North American Journal of Economics and Finance, 18(1), 23-40, 2007.

[12] Koopman, R., Powers, W., Wang, Z., \& Wei, S.-J. , "GIVE CREDIT WHERE CREDIT IS DUE: TRACING VALUE ADDED IN GLOBAL PRODUCTION CHAINS “, NBER Working Paper 16426, 2011.

[13] Kowalski, P., Lopez Gonzalez, J., Ugarte, R., and Cristian, A.,"Participation of Developing Countries in Global Value Chains," OECD Trade Policy Papers, 179, April 2015.

[14] Krugman, P., "The Return of Depression Economics and The Crisis of 2008 (1 st), “. New York: W. W. Norton \& Company, Inc. , 2009.

[15] Lall, S., Albaladejo, M., \& Zhang, J., "Mapping fragmentation: Electronics and automobiles in East Asia and Latin America," Oxford Development Studies, 32(3), 407-432, 2004.

[16] Nurunnisa, A., \& Hastiadi, F. F., “ Real Exchange Rate, Trade Balance and Deindustrialization in Indonesia," In A. Banik, M. K. Barai, \& Y. Suzuki (Eds.), Towards A Common Goal: Understanding Growth Sustainability of the Asia Pacific Region (1st ed., p. 322). Palgrave Macmillan, 2017.

[17] Soejachmoen, M. P., "Globalization of the Automotive Industry: Is Indonesia Missing Out?", Asian Economic Papers, 13(1), 84-103, 2014.

[18] Sturgeon, T. J., "Mapping Global Value Chains: Intermediate Goods Trade and Structural Change in the World Economy". Development Policy and Strategic Research Branch Working, 2010 